\title{
WORDSWORTHS POETIK
}

\section{Hans Hauge}

"Eine Definition der Poesie kann nur bestimmen, was sie sein soll, nicht was sie en Wirklichkeit war und ist; sonst wïrde sie am kürzesten so lauten: Poesie ist, was man zu irgendeiner

Zeit, an irgendeinem Ort so genannt hat". Schlegel, AF 114

"...Wordsworth played an important role in the eighteenth-an early nineteenth century form of the deconstruction of metaphysics.."

J. Hillis Miller

1.

Poetik er at finde forskelle. Generelt handler poetik om, hvordan digte adskiller sig fra ikke-digte, og det vil sige on dét, der gør digte til digte: poeticitet. Specielt kommer det her til at handle om, hvordan romantiske digte adskiller sig fra ikke-romantiske digte, og det vil sige om det romantiske digts differentia specifica: dets 'romanticitet' om man vil. Endnu mere specielt handler det om, hvordan et

Wordsworth-digt adskiller sig fra andre romantiske og ikke-romantiske digte. Om det at gå ind i et digt af Wordsworth siger J. Hillis

Miller følgende: det er at "open the gate into a place of ceaseless

labyrinthine wandering, just as is the case, in a different way, with

the poetry of Stevens and even that of Arnold"1. Det lover ikke

godt for en bestræbelse på en bestemmelse af Wordsworths 'poetik'.

Beedre bliver det ikke, når vi også hos Hillis Miller kan læse os til, at

kilden til "the irresolvable ambiguities of Wordsworth's verse is the

originally figurative nature of language $\mathrm{e}^{\prime \prime}$. Hvis poetisk ambiguitet

J. Hillis Miller, The Linguistic moment p.53.

lbid., p.47. 
skyldes sprogets oprindelige figurativitet, da må al poetisk sprog være dobbelttydigt, og vi synes da på sporet af en generel bestemmelse, skønt negativ, af, hvad der konstituerer poetisk sprog som sådan. Hillis Millers tendentielt universelle bestemmelse af det poetiske sprog støder nu sammen med mit Schlegel-motto, der romantisk - radikalt historiserer, hvad poesi er. Er Hillis Millers dicta da blot udtryk for, at "Poesie ist, was man zu irgendeiner Zeit, an irgendeinem Ort so genannt hat"? På denne tid og på dette sted bestemmes poesi som ikke-ophævelige dobbelttydigheder og endeløse labyrintiske vandringer? At sige sådan om en vis form for poesi, som Stevens', eller måske om Borges' eller Ecos, ville næppe provokere til modsigelse, men hvad sker egentlig, når disse udsagn er møntet på Wordsworth eller endog på Arnold? Har Hillis Miller dermed universaliseret indsigter, der kunne skyldes mødet meç tekster som Stevens' (eller Borges')? Mere banalt kunne vi spørge, om vi altid læser fortidige tekster med nutidens poetiske øjne uden agtelse (respect, Achtung) for de fortidige teksters egenart? Vil en poetik, dvs. en teori om det poetiske sprog, altid være ahistorisk? Vil den det, da opstår et særligt problem i omgangen med det romantiske digts særegenhed, idet romantikken, on vi lader Schlegel være repræsentativ, historiserer og relativerer, hvorved den på sin vis sætter spørgsmålstegn ved selve poetikkens projekt. For poetikken vil jo svare på spørgsmålet om, hvad er poesi? Og den er ikke tilfreds med kun at svare på spørgsmålet her og nu eller der og dengang. Men hvis nu, hvad allerede er antydet, det romantiske digts egenart måske består $\mathrm{i}$, at det ingen egenart har; at det på en måder derfor er ubestemmelig, så synes der at opstå problemer, som vi vist ikke læser her og nu. Lad mig derfor forlade problemet og bevæge mig ind på lidt sikrere grund. Vi kunne indføre en skelnen mellem en universel og så en relativ poetik. At finde træk ved litteraturen, der gælder al litteratur, er en universalistisk tænkning, og den kan siges at kendetegne, hvad vi forstår ved en strukturalistisk poetik. Eṇ relativ poetik, derimod, ville redegøre for de træk, der til en bestemt tid, i en bestemt litterær epoke eller for en gruppe af digtere udgjorde 'det poetiske'. Vi kunne på den måde, med lidt held, bestemme f.eks. hvad der var det særlige ved Wordsworths digte uden dermed. at sige noget om andre digte ira andre epoker. Igen kompliceres denne fremgangsmåde af, at selve differentieringen $i$ en universel og en relativ poetik er knyttet til romantikken, en sådan differentiering er afhængig af, at vi kan adskille det romantiske digt fra et ikkeromantiske digt. Wordsworth sagde om de digte, han havde inkluderet i Lyrical Ballads, at de var "materially different", fra hvad man før havde set. 'Dette er et signal om, at noget nyt var sat i verden
Hvis hans digte er eller var materielt set forskellige, da må denne forskel kunne identificeres

2.

Vi har nogle traditionelle æstetiske kategorier, hvormed vi i undervisning og i litteraturhistorier arbejder uden hele tiden at skulle vende og dreje dem. Lad mig for en sikkerheds skyld holde mig til dem. Og traditionelt opererer vi med et brud mellem romantikken og det, der kom før, hvordan vi så end betegner de før-romantiske epoker. Det æstetisk-retoriske begreb, hvormed man differentierede i tiden før romantikken, var naturligvis mimesis. Fra Aristoteles og op til romantikken var litteratur (og kunst) mimesis, og det uanset hvilken forståelse vi har af begrebet. Pædagogisk kan vi formulere mimesis som en teori om, at poesi var udtryk for et indtryk. Noget skulle så at sige trykkes ind, før det kunne trykkes ud. Bedst var det naturligvis, om man fik indtryk fra naturen, virkeligheden eller lignende, men sikker kunne man aldrig være. For nu at være sikker på, at man imiterede naturen - hvilken var den eneste sikring af litteraturens sandhed - så imiterede man Virgil, for han havde imiteret Homer, og Homer imiterede naturen. Med romantikken sker så det, og igen følger vi den traditionelle litteraturhistoriografi, at poesien, fra at være udtryk for et indtryk, bliver ren udtryk. Mimesis afløses af ekspression. Men udtrykket skal ikke først have et ind tryk. Poesien ophører med at give udtryk for indtryk, men udtrykker et indre. Udtryk kommer før indtryk. Det var noget som Grundtvig ikke kunne forstå, men han kunne heller ikke forudse, at denne romantiske ekspressionsæstetik kom til at vinde så megen indpas, at alle idag strot set lever af den. Denne romantiske æstetik er idag den foleklige æstetik. Hvad $\in \mathrm{r}$ kunst? Det er en kunstner, der giver udtryk for sit indre, og dermed gør indtryk på os. T. S. Eliot kæmpede som bekendt mod denne æstetik ved at sige, at en digter ikke giver udtryk for sig selv og sit selv, tværtimod er det at digte at flygte fra sit selv. En digter er 'blot' en katalysator. Dermed fremstod ideen on den usynlige, upersonlige digter, og denne ide kulminerede i Roland Barthes' og Foucaults proklamationer om forfatterens 'død'. Denne sidste, og endnu ikke folkeligt accepterede, modernistiske ide er blot afslutningen på et forløb, der begyndte, da eks-pression afløste mimesis. Hvordan det? Ja, lad os bevæge os over i et andet regi, idet jeg hele tiden vil understrege, at jeg følger den traditionelle historiografi, og det vil sige, at jeg hele tiden er mig bevidst, at al tale om brud i historien er metaforer, og at de kategoriseringer jeg og tradiionen foretager er pseudo-kategoriseringer. 
Jeg vender tilbage til mimesistænkningen igen. Den var naturligvis også religiøst funderet. Ganske vist stod den vestlige litteratur på Homer, men kun med det ene ben. Det andet ben var Bibelen. Mimesis kunne lykkes, fordi naturen var en bog eller tekst. Den var forfattet af den store Forfatter (auctor/auctoritas): Gud. Bibelen var Guds bog, en sikker mimesis af verden. Imiterede man den bog imiterede man verden. Når teksten, dvs. den sækulære tekst, i dag har mistet $\sin$ forfatter, altså sin auctor og dermed auctoritas, da gentager det blot den proces, der gik ud på at 'verden' mistede sin forfatter. Verden, naturen, var nu blot en tekst uden mening, fordi en tekst kun får mening, fordi den er forfattet. Og ganske som vi idag siger, at læseren skal give den betydningsløse tekst mening, således skulle den romantiske læser, dvs. digter, nu selv til at give verden mening. Det gjorde digteren ved at kaste sit lys ud i mørket og intetheden, og idet digteren kastede sit lys ud i verden, se, da blev verden til påny. Digteren oplystes ikke længere af et ydre lys (indtryk), for verden var øde og mørk. Der skal lys til at lave mimesis, og det vil sige, at mimesis kan godt fortsætte, men lyset er fra nu af kunstigt lys. Dette kunstige lys frembragtes af fantasien - altså netop finta-sien. Det særlige ved fantasien er, at den ikke behøver ydre indtryk. Den kan selv. At se det er at skabe. Sagde Blake noget i retning af. Når ekspression afløser mimesis, så løses litteraturen fra litteraturen. Romantik er på sin vis en revolte mod det litterære og derfor også mod det litterære sprog. Litteratur blev før romantikken til litteratur ved at imitere litteratur, for det var på den måde mimesis praxcos blev forstået i praksis.

Hvad er nu konsekvenserne af bruddet mellem mimesis (repræsentation) og ekspression (kreativitet)? Negativt var det et opgør med tidligere tiders æstetik og poetik, positivt var det en insisteren på og en indsættelse af det ıy/ som æstetisk kategori. Før romantikken skulle poesien hverken være ny eller original, det skal den efter Denne romantiske æstetik har vi også arvet og taget til os. Coleridge sagde, at poesien skulle fjerne "the film of familiarity", og det vil sige at defamiliariscre ${ }^{3}$. Det gamle skulle gøres nyt ved at blive set på en ny måde. Se, jeg gør alting nyt, sagde digteren, idet han citerede Jesus. Ung må verden endnu være. Der må derfor også et nyt sprog til, men det kan kun være nyt, ved ikke at ligne det gamle; det man kaldte 'poetic diction' i den engelske tradition ${ }^{4}$

3 S. T. Coleridge, Biographia Literaria, red. af George Watson (Everyman's Library, Dent, London: 1967), s.169. Der gảr naturligvis en lige linie fra denne romantiske æstetik (om at fjerne bevidsthedens og vanens slør) til formalismens og strukturalismens ideer om defamiliarisering og de-automatisering

4 Om opgøret med 'poetic diction'-tanken, f.eks. Grays synspunkt, at poesien
Det nye, som kategori, er en vanskelig håndterbar een. Hvis man nemlig virkeligt skal skrive på en ny måde, hvordan kan man så se, at det man skriver er digtning? Før kunne man let se forskel. Litteratur var aksiomatisk set litteratur, og det betyder ganske enkelt, at litteratur kunne ikke være andet end litteratur ${ }^{5}$. Men hvis man ikke vil følge konventionen, da kommer litteraturen til at ligne ikke-litteratur, og hvad er da det specifikt litterære? Nu skete der naturligvis det, at det nye ikke forblev nyt. En konvention etablerede sig. Vi fik noget, der hed det traditionelt nye. Et romantisk digt kunne genkendes, fordi det altid handlede om det samme. Så det nye blev det gamle. Følger vi den traditionelle opdeling af litteraturen, så kom modernismen til, og vi skal ikke her skændes om hvornår, vigtigt er det kun at fastslä, at den forstod sig selv som et opgør, som noget nyt, i forhold til romantikken. Derfor er det, at man kan se modernismen som et romantisk opgør med romantikken, som Frye siger. Som metasprog til modernismen opstår to forsøg på igen at bestemme det poetiske sprogs særegenhed. Der er dels den strukturelle poetik og dels den anglo-amerikanske ny kritik (Newv Criticism). For begg gælder det, at hverken mimesis eller ekspression kan bruges som differentia specifika, og hvad er der så tilbage?

Sproget. Det er sproget, der gør det. For ny kritikeren var poesiens sprog paradoksets sprog (Cleanth Brooks), for strukturalisten var det, der gjorde poesien poetisk, en dominans af den 'poetiske funktion'. Den poetiske funktions dominans kunne beskrives objektivt og lingvistisk. Havde man den rette strukturelle lingvistik, så kunne man se poesi, når den var der, nemlig når ækvivalensaksen var projiceret over på kombinationsaksen. Sådan lyder det kort og uforståeligt for dem der ikke kan deres Jakobson. Det er ikke udredningen, der er det vigtigste, men princippet: man kan identificere poesien, man kan redegøre for poeticiteten universelt. Det må gælde alle tilfælde, fordi sproget er universelt. Sprog virker ens, uanse hyilket sprog det er. På dette punkt her da synes den strukturelle poetik at være en genoptagelse og en genopdagelse af indsigter fra den før-romantiske tænkning. Og det er da også rigtigt. Roman Jakobsen gjorde hele tiden opmærksom på, at den strukturelle lingvistik havde ikke 'opfundet' noget nyt, men blot genopdage indsigter, der var blevet tilsløret af, tror jeg, det nittende århundredes vranglære.

var et sprog "peculiar to itself", se især eller f.eks. F.W. Bateson. English Poetry and the English Language (Oxford: 1934).

5 Ideen om noget der aksiomatisk set er litteratur findes i David Lodges The Modes of Modern Writing. 
Hvad nu med Wordsworth? Hvordan kommer vi fra disse overordnede betragtninger ned til det konkrete? Wordsworths Lyrical Ballads udkom i 1798, og de er begyndelsen på den engelske romantik. Og det er jo ganske behageligt således at kumne tidsfaste uden vaklen en begyndelse på noget nyt og anderledes. Hvad var så nyt og anderledes ved dem? Det er straḱks vanskeligere at afgøre, eller rettere: det vanskelige er. at afgøre, om det er let eller vanskeligt at afgøre det. For Wordsworth var det at skrive et digt et løfte. Skriver afgøre det. For Wordsworth var det an skriver også er et digt. Digteren, som Wordsworth kalder "the Author", indgår en "formal engagement" med sin laser om, at han vil opfylde visse ting. Han lover, når han digter, at han vil inkludere visse ideer og udtryk, og at han vil udelade andre ideer og udtryk. Hvad der skal tages med i bogen, og hvad der ikke skal tages med, forudsætter en konvention eller et sæet af regler. For at kunne love noget, så må der være en. konvention, der gør det muligt overhovedet at love. Men hvordan kan man så egentlig skrive et helt nyt digt? Hvis det at skrive et digt, ligesom det at afgive et løfte, forudsætter kendte og anerkendte konventionelle procedurer, hvordan kan man så skrive et digt, der bryder med disse konventioner? Det var Wordsworths problem. Han havde - sammen med Coleridge - skrevet nogle digte, men han vidste, at mange ville have besvar med at se, de var digte. Han lovede noget, men han var ikke sikker på, at lreserne opfattede det som om, han havde holdt sit løfte. Derfor skrev han til den første udgave af Lyrical Ballads en "Bekendgørelse" - the Adtvertisment (1798). Denne blev udvidet til andenudgaven og blev til et forord (1798). Denne ble
the Prefince (1800).

At love noget, ligesom at digte, er en performativ handling. For at en sådan talehandling kan lykkes, så skal man være den rette til at udføre den. Man skal altså være digter. Hvordan kumne Wordsworth nu vide, at han var den rette? Hvordan ved digteren, at han er udvalgt? I første bog af The Prelutc skriver Wordsworth som en profet og henvender sig til "the open field (1.59)", at "poetic numbers came spontaneously", og at hans ånd følte sig "singled out", og at han havde "great hopes", men er det nu også nok?

Omstændighederne eller situationen skal også være passende, og det vil sige, at der skal være vedtagne konventioner, som allè skal være enige om, før en talehandling, som at digte, kan udføres. Jeg kan f.eks. ikke udfordre en rival til duel i universitetsparken, fordi der ikke længere findes en konventionel procedure for at udføre en sådan talehandling. Endelig skal modtagerne, de personer, som talehandlingen udføres for og med, acceptere handlingen og være villige til at vare handlingens modtagere.'Jeg kan ikke love noget, hvis dem jeg lover noget ikke er indforståede med det. Hvad gør man så i den situation, hvor de digte, man lover, ikke ligner digte? Er de så digte? Hvordan kan man bevise, at et digt er et digt, når det ikke ligner et digt? Det var Wordsworths problem i The Preface: "I will not take upon me to determine the exact import of the promise which by the act of writing in verse an Author, in the present day, makes to his reader". Hvad betyder, og hvad er meningen (import) med dette digt-løfte idag? Nøjagtigt kan han ikke redegøre for det, men han forsøger alligevel med forordet, og forordets ide bliver da for ham at 'state', hvad det var han i digtene havde 'performed'. The Preface er da, i et lidt andet sprog, konstativt medens digtene er performative. Han siger i forordet, og det vil sige bagefter, hvad han udførte i og med den skrivehandling (act of writing), det er at skrive vers. Wordsworth siger, at det han skriver er digte, selvom man ikke kan se det, for det nye ved dem er det, at man ikke kan se, at de er digte, hvis man ikke først fik det at vide - i et efterskrevet forord.

Digtene i Lyrical Ballads var "materially different" i forhold til de digte, der dengang var anset for moderne. De læsere, der var væennet til moderne digte, ville, når de læste bogen med de lyriske ballader, "look round for the poetry" og de ville spørge med hvilken ret, "these attempts can be permitted to assume that title", og det vil sige titlen poesi. En titel er jo også et løfte. Hvorfor behøvede Wordsworth digte et forord, når de efter hans eget udsagn var "materially different"? Hvad gjorde forskellen? Forordet eller digtene? Eller kan vi slet ikke skelne, fordi vi altid og kun møder digtene efter forordet og dermed på forhånd ved, at de er forskellige? Vi nærmer os nu det der her er temaet; Wordsworths poetik. Findes den fremsat (stated) eller udført (performed)?

Det han siger, at han gør, er at tilpasse til et metrum en udvalgelse af "the real language of men". Sproget skal ikke vare 'poetisk', men virkeligt. Det materielt forskellige består i at tage et andet materiale, nemlig "the incidents of common life". Altså at vise, at hverdagen var interessant. At gøre det bekendte nyt igen. Endelig finder vi også i Forordet den berømte udtalelse om, at god poesi er "the spontaneous overflow of powerful feelings". Så har vi citeret de mest omtalte steder fra Forordet. Sådanne udtalelser var nok dengang nye, skont vi idag har svaert ved at se det, fordi de nu er klicheer. De synes blot at sige noget i retning af, at digtere skal skrive om almindelige mennesker og tale så folk forstår dem. Jeg er her altså ikke synderlig interesseret i, hvad Wordsworth siger i Forordet, men i at han siger det. Han skriver nemlig digte, der ikke lignede digte, men 
som vi idag godt kan se er digte, fordi han bekendtgjorde, at de var digte. Wordsworths poetik, eller poesidefinition, minder derfor on Schlegels institutionelle definition, og en sådan definition er ikkesubstantiel. På en måde bliver Wordsworths Forord derfor performativ, snarere end konstativ. Han siger, at det han har skrevet er digte, og derfor blev de digte: Poesie ist, was man zu irgendeiner Zeit, an irgendeinem Ort so genannt hat. Wordsworth har benævnt digtene ind i eksistens. Han har frasagt sig en universalistisk definition af poesi:

This cxponent or symbol held forth by metrical language must in different aeras of literature have excited very different expectations: for example, in the age of Catullus T'crence and Lucretius, and that of Statius or Claudian, and in our own country, in the age of Sliakespeare and Beaumont and Fletcher, and that of Donne and Cozuley, or Dryden or Pope. I zuill not take upon me to determine the exact import of the promise zulich by the act of zoriting in verse an Author, in the present day, mukes his reader; but I am certain it zoill appear to many persons that I have not fulfilled the terms of an engagentent thus voluntarily contracted.

Vi nærmer os nu en konklusion af foreløbig art. I og med romantikken bliver det umuligt at finde demarkationslinjen mellem poesi og ikke-poesi. Det var dette, som bl.a. satte Roman Jakobson igang, ide hans udgangspunkt var, at poesi er en labil kategori, medens 'poeticitet' (básnickost) er konstant.

Poeticitet manifesterer sig på den måde, at "ordet, opfattes som ord, og ikke blot som reprasentant for det benævinte objekt eller følelsesud tryk". Ordet opfattes som ord, og hverken som mimesis eller ekspression for nu at omformulere Jakobsens ord i forhold til dem, jeg har brugt. Denne definition ligger naer det, som J. Hillis Miller forstår ved "the linguistic moment", det sproglige øjeblik.

4.

Der er en ting, man altid kan sige om Wordsworths poesi, og det er, at den til forskellige tider og på forskellige steder er blevet bedømt så forskelligt. Der er kun få konstanser i bedømmelsen af ham. Somme tider har man anset det, han sagde som banalt, andre tider er har blevet betragtet som en stor filosof. I epoken efter T. S. Eliot var tendensen helt klart at afkanonisere ham. Hans poesi passede dårligt til nykritikernes opfattelse af, hvad poesi var (ironi, kompleksitet, 'wit', paradoks). Bemærkelsesværdigt er det også, at da Northrop Frye gik igang med en rehabilitering af romantikken, da var det stort set aldrig Wordsworth, som han rettede sine analyser imod. I en anden onvurdering af romantikken, den som vi finder hos $\mathrm{M}$. H. Abrams bogerne The Mirror and the Lamp og i Natural Supernaturalism, stå Wordsworth imidlertid centralt som digter og som tænker. I sammenhæng med opvurderingen på det litterære marked af Wordsworth er der sket en gradvis nedskrivning af makkeren - og filosoffen - Coleridge. Det skyldes givetvis, at nykritikerne hos Coleridge fandt belæg for deres holisme og organicisme. Ligeledes kan man se, at Blake er gledet i baggrunden. Blake var basis for Northrop Frye og Blake-renæssancen fandt sted i slutningen af tresserne, for var det ikke Blake, der satte fantasien i centrum? I Yaleskolens genlæsning af romantikken er det så, at Wordsworth står så stærkt igen, og vi har her en af forklaringerne på, at MI. H. Abrams og Hillis Miller har udkæmpet en kamp om bl.a. forståelsen af ham. I den danske reception af den amerikanske dekonstruktionisme har det nok undret mange, tror jeg, at Wordsworth har den centrale stilling, som han har, så central at Hillis Miller, som jeg har citeret i mit andet motto, kan udnævne ham til en, der har spillet en central rolle i det nittende århundredes dekonstruktion af metafysikken: man sporger "det nittende århundredes hvad?" Vi må huske, at Miller siger dette på baggrund af , at den almindelige mening er, eller i al fald var, at Wordsworth var repræsentant for den romantiske primitivisme. Det synes som om, man kan komme godt fra at sige hvad som helst om Wordsworth. Skyldes det nu, at selve kategorien poesi er labil, som Jakobsen hævdede, skyldes det, at Wordsworths digtning er labyrintisk, som Miller hævder, eller skyldes det, at Wordsworths digte er så substansløse, at det er op til læseren på et bestemt sted og til en bestemt tid at gøre ved tekstene, hvad han vil? Hvordan kan den samme digters digte være uskyldige, lyriske naturskildringer; dybe filosofiske tekster ligefremme gengivelser af det sprog, som almindelige mennesker taler; primitivistiske og nostalgiske udgydelser; vigtige bidrag til dekonstruktion af metafysikken? Hvem har ret? Det underlige er nu for det første det, at det er lykkedes Hillis Miller, Paul de Man og Geoffrey Hartman at læse Wordsworth, som de gør: lad os bare i første omgang sige at rekanonisere ham. Jeg tror ikke, at de kunne have gjort det med f.eks. Blake eller Coleridge. Forklaringen på denne intuition har jeg ikke. Men nu begyndte jeg med at gengive en traditionel beskrivelse af, hvad romantikken var (bruddet med mimesis, indsættelsen af ekspressivismen). Det er imidlertid tvivlsomt; om ovennævnte litteraturteoretikere arbejder med en sådan brud-metaforik overhovedet. Den passer nemlig dårligt på Words- 
worth; for det er vist ikke noget nyt at sige, at adskillige kritikere har haft ganske meget besvær med at sige, hvad der var det romantiske ved Wordsworth, vel at mærke når vi benytter ordet 'romantisk' den traditionelle betydning. Derrida, f. eks., arbejder ikke med et brud mellem det attende og det nittende århundrede. Hos ham lever vi endnu i repræsentationens og dermed i mimesis' epoke. Nu har jeg til lejligheden defineret mimesis som ud tryk for et ydre ind tryk. I det attende århundrede tolkedes dette som imitation af anden litteratur, hvorved ind trykket var højst medieret. Skulle en digter skrive et hyrdedigt, så kunne han bare se på, hvordan Milton, Virgil, Theokrit eller Bion havde gjort det, men Wordsworth ville ikke kigge i poesibøgerne. Han ville gerne skrive hyrdedigte, men om rigtige hyrder. Han gik, så at sige, ud og opsøgte en hyrde, hørte på ham og skrev, f.eks. digtet Michael. Wordsworth skrev mange gange 'pä' indtryk (influxes). Det var ofte for ham et ideal ikke at fortolke omverdenen, men umedieret at gengive den. Det er en side af hans poesi, der ville have tiltalt $\mathrm{K}$. E. Løgstrup. Wordsworth insisterede på sansningen. For ham gjaldt det ikke, som for Blake, at "perception is creation". For Wordsworth er der harmoni mellem bevidsthed og ydre verden. Men det er det ydre, som sætter ham igang: den "gentle breeze" der kommer til ham i Book First af The Prclute. Denne ydre "breeze" modsvares af en indre "corresponding mild creative breeze (1.43)". Vi ser her et eksempel på Wordsworths epistemologi, Forholdet mellem bevidsthed og ydre verden er som et ægteskab, hvor begge parter bringer lige meget med. Bevidstheden yder sit, den ydre verden sit. Vi halvt skaber og halvt sanser. Det er denne Wordsworth, der er mest kendt, nemlig den, hvor "the analogical correspondence between man and nature is so perfect that one passes from one to the other without difficulty or conflict", som Paul de Man siger i et essay om Wordsworth og Hölderlin. De Man siger dette i forbindelse med en læsning af et digt fra Lyrical Ballats, der hedder The Boy of Winander og som indgik som en del af The Pre lude, (bog 5). Overensstemmelsen mellem indre og ydre, mellem. menneske og natur, mellem bevidsthed og omverden viser sig dog altid hos Wordsworth at være, som Paul de Man siger, illusorisk. det omtalte digt ind finder der sig pludselig en "tone of uncertainty", fortsætter de Man. Naturen tier, og så sker det, at i den efterfølgende stilhed, da står der hos Wordsworth: "while he hung/Listening ... (V. 406)". De Man kommenterer dette "hung". Hvad betyder det at hænge lyttende? Dette fører til Paul de Mans tolkning af forskellen mellem 'fancy' og 'imagination', den skelnen mellem to former for indbildningskraft, som især Coleridge i Biographia Literaria indførte.
Ifølge Paul de Man er forskellen på fancy og imagination, at den forste fantasi-form (den 'lavere') afhænger af et forhold mellem bevidsthed og natur, mens den anden form er visionær, hvilket betyder, at den defineres som sprogets (imaginationens sprog) mag (power) til ikke at være imitativt og repetitivt tro mod sansningen (sense perception). Når Paul de Man - og Wordsworth - taler on fantasien, da er det ikke en celebrering af det kreative og af den skabende drift eller bevidsthed. Fantasi er dødserfaring. Fantasi er tabet af "the sense of correspondence". Og det er klart, at når vi erfarer dette tab af sansen for eller sansningen af overensstemmelse, da er det at erfare døden i et øjeblik. Paul de Man har kredset om dette moment hos Wordsworth. Jeg citerer da et af de berømte steder fra The Prelude om fantasien, der viser den som dels virkende uden noget ydre har sat den igang (den er 'unfathered'), og dels som forårsagende det, der må være døden, at verden forsvinder. Wordsworth i Alperneopdager, at han er kommet over passet uden at have set det:

Imagination! lifting up itself

Before the eye and progress of my Song

Like and unfather'd vapour; here that Power,

In all the might of its endowments, came

Attwart me; I was lost as in a cloud

(VI. 525-29)

Med dette romantiske syn på fantasien bliver det svært at forstå, at velmenende pædagoger mener børn skal have bedre muligheder for at udvikle deres fantasi, for så er de, som det siges, 'lost'. I digtet The Boy of Winander sker en overgang fra perception til imagination, det vil sige fra et mimetisk til et konstitutivt sprog. Blandingen af disse to sprog, altså den glidende overgang fra bevidsthed til natur, kalder de Man nostalgi efter objektet (i det tidlige essay Intentional Structure of the Romantic Image). Den art nostalgiske eller illusoriske øjeblikke findes hos romantiske digtere, men de Man insisterer igen og igen på, at om det lykkelige forhold ("happy relationship") mellem materie og bevidsthed kan man ikke tale uden først at tage højde for at forholdet skal etableres i sproget, hvilket betyder, at forholdet ikke eksisterer i virkeligheden ("in actuality").

Nu.har jeg flere gange talt om en overgang fra mimesis til ekspression, og jeg har identificeret overgangen som en fra det attende ạrhundrede til det nittende eller fra representation til kreativitet eller endog fra oplysningstid til romantik. Paul de Man synes at tale om det 'samme' i analyserne af Wordsworth, som jeg kun stikords- 
agtigt har gengivet, idet han taler om en overgang fra perception til imagination eller fra et mimetisk-bogstaveligt til et ekspressivtkonstitutivt sprog. Men for de Man er der tale om lingvistiske kategorier, som man ikke legitimt kan gøre til astetiske, hvilket sker, når man bruger dem som litteraturhistoriske periodebetegnelser.

Jeg slutter af med et par refleksioner over Hillis Millers' laesninger af Wordsworth. Sådan begyndte jeg også. At laese Wordsworth sagde han, var at åbne porten til labyrintiske vandringer, og han talte om uløselige dobbelttydigheder. Det samme gjorde de Man. Det er på grund af disse uophaevelige ambiguiteter, at hans poesi ikke kan tilordnes en entydig periode.

Laesninger af Wordsworth, siger Miller, søger altid at identificere det centrale eller oprindelige element, der muliggør forskellige former for forsoninger. Hvad er det element, sporger han, "on which the others depend or from which they derive?". Et systematisk hele forudsatter altid et center, men hvor er centret hos Wordsworth: er det naturen (objektet), er det anden i naturen, er det bevidstheden eller er det sproget? Det er det, man ikke kan afgøre, og det er da det, der er det sarlige ved Wordsworths poetiske sprog; det er dets 'uncertainty'. I digtet Resolution and Indepenterice er der, ifolge Miller, ikke en oprindelse, ingen grund under digterens glaede, pa basis af hvilken de andre kan berskrives som figurer. Kilden til denne uophaevelige ambiguitet er sprogets oprindelige figurativitet, og som Miller tilføjer "though the normal concept of source is in this case suspended". Det, der så står tilbage, er spørgsmålet, om al poes så ikke, skont på forskellig måde, altid må vare uophavelig dobbelttydig, hvorved projektet om at bestemme det altid må slå fejl. 